\title{
Association between the rs 12255372 variant of the TCF7L2 gene and obesity in a Cameroonian population
}

\author{
Elvis Ndonwi Ngwa ${ }^{1,2}$, Eugene Sobngwi ${ }^{2,3,4^{*}}$, Barbara Atogho-Tiedeu ${ }^{1,2}$, Jean Jacques N. Noubiap ${ }^{5,6}$, \\ Olivier Sontsa Donfack 1,2, Magellan Guewo-Fokeng 1,2, Edith Pascale Mato Mofo ${ }^{1,2}$, Priscille Pokam Fosso 1,2, \\ Eric Djahmeni ${ }^{4}$, Rosine Djokam-Dadjeu ${ }^{1,2}$, Marie-Solange Evehe ${ }^{1,2}$, Folefac Aminkeng ${ }^{7}$, Wilfred F. Mbacham ${ }^{1,8}$ \\ and Jean Claude Mbanya $2,3,4$
}

\begin{abstract}
Background: The transcription factor 7-like 2 (TCF7L2) is one of the genes that have been identified as possible determinants of diabetes which is associated with obesity. Data on the genetic causes of obesity in sub-Saharan African populations are very scares. The aim of this study was to assess the association between the transcription factor 7-like 2 (TCF7L2) gene polymorphism (rs12255372 G/T) and obesity and weight-related traits in a Cameroonian population.
\end{abstract}

Methods: A case-control study was conducted on 35 obese and 30 non-obese Cameroonian adults. TCF7L2 rs12255372 genotypes were determined using PCR-RFLP and correlated with BMI and weight-related traits.

Results: No significant association was observed between the rs12255372 T allele $\left(x^{2}=0.0684, p=0.79\right)$ or the TT genotype ( $x^{2}=0.372, p=0.54$ ) of the TCF7L2 gene and obesity in the Cameroonian population. However, amongst the weight-related traits, triglycerides were significantly associated with the T risk allele of the TCF7L2 gene $(p=0.012)$.

Conclusion: This study on Cameroonian subjects replicates the absence of association between the TCF7L2 rs12255372 variant and obesity as observed in European and American populations.

Keywords: Obesity, Transcription factor 7-like 2 (TCF7L2), Cameroon, Sub-Saharan Africa

\section{Background}

The rising prevalence of overweight and obesity constitutes a global pandemic. The number of overweight and obese individuals increased from 857 million in 1980, to 2.1 billion in 2013 [1]. In 2010, overweight and obesity were estimated to cause 3.4 million deaths, $4 \%$ of years of life lost, and $4 \%$ of disability-adjusted life-years (DALYs) worldwide [2]. In Cameroon, the prevalence of overweight or obesity among adults aged $\geq 15$ years increased from $22.5 \%$ in 2002 to $26 \%$ in 2006 [3, 4].

\footnotetext{
*Correspondence: sobngwieugene@yahoo.fr

${ }^{3}$ Department of Internal Medicine and Specialties, Faculty of Medicine and Biomedical Sciences, University of Yaoundé I, Yaoundé, Cameroon Full list of author information is available at the end of the article
}

Obesity results from an imbalance between energy intake and expenditure which is influenced by a variety of multiple factors that could be environmental, psychosocial and genetic [5]. Although this epidemic is attributable to the trend of decreased physical activity and increased calorie intake, these external factors play out on a genetic background that determines body mass and susceptibility to obesity-related diseases [6] and so, common forms of obesity have a strong hereditary component. Depending on the population examined, these genetic factors may account for $6-85 \%$ of the cases [7]. However, the genetic pathways that contribute to obesity have not yet been elucidated.

The transcription factor 7-like 2 (TCF7L2) gene is one of those that have been identified as possible 
determinants of type 2 diabetes mellitus (T2DM). It codes for a transcription factor with a high-mobility box which is one of the components of the Wingless type (Wnt) signaling pathway, initially characterized in colon cancer and in the embryonic development of some organisms such as Drosophila [8]. Wnt pathways are a group of signal transduction pathways made of proteins that pass signals from outside of a cell through cell surface receptors to the inside of the cell. Three have been characterized including the canonical Wnt pathway, the non-canonical planar cell polarity pathway and the noncanonical Wnt/calcium pathway. It has been shown that in adipocytes, the canonical Wnt-signaling via TCF7L2 down-regulates adipogenesis [9]. Although TCF7L2 was not identified as a risk factor for obesity in a study involving European populations, its effect on the risk for T2DM was modulated by obesity [10]. Additionally, a study revealed that the rs 12255372 variant of TCF7L2 was protective for obesity in Mexican children [11]. These findings warrant further investigation of the role of TCF7L2 in obesity among various ethnic populations. We previously reported on the $\operatorname{rs} 12255372(\mathrm{G} / \mathrm{T})$ and rs7903146 (C/T) polymorphisms of TCF7L2 as risk factors for type 2 diabetes mellitus in a Cameroonian population [12, 13], however to the best of our knowledge, the association between rs12255372 (G/T) and obesity has not been explored in any African population till date. The aim of this study therefore was to assess the possible association of the TCF7L2 rs12255372 polymorphism with obesity and weight-related traits in a Cameroonian population. Findings may contribute to further investigations for the understanding of the causal role of heredity in obesity which may foster successful interventions and treatments.

\section{Methods}

\section{Study population}

A case-control study was conducted that involved 35 obese (BMI $\geq 30 \mathrm{~kg} / \mathrm{m}^{2}$ ) and 30 non-obese $\left(18 \leq \mathrm{BMI}<25 \mathrm{~kg} / \mathrm{m}^{2}\right)$ adults of Cameroonian origin, aged 20 years and above. Obese patients were recruited from the Outpatients Clinic of the National Obesity Center of the Yaoundé Central Hospital, and non-obese controls from the general population between February and April 2011. Diabetic patients and pregnant women were excluded from the study. For all participants, data was collected on the sex and age. Height, waist and hip circumference to the nearest $0.5 \mathrm{~cm}$ were measured, as well as weight in light clothes to the nearest $0.1 \mathrm{~kg}$. The body mass index (BMI) as weight in kg divided by height in meters squared $\left(\mathrm{m}^{2}\right)$, and the waist-to-hip ratio as waist circumference $(\mathrm{cm})$ divided by hip circumference $(\mathrm{cm})$ were calculated. Obesity was defined as
BMI $\geq 30 \mathrm{~kg} / \mathrm{m}^{2}$. The resting blood pressures were measured using standardized procedures with an automatic sphygmomanometer Omron HEM-705 CP (Omron Corporation, Tokyo, Japan).

\section{Biochemical assays}

Fasting plasma glucose (glucose oxidase-peroxidase method), serum cholesterol (cholesterol oxidase phenol-4-amino antipyrene peroxidase method), serum triglycerides (glycerol phosphatase oxidase phenol4-amino antipyrene peroxidase method), and high-density lipoprotein (HDL)-cholesterol (cholesterol oxidase phenol-4-amino antipyrene peroxidase method) were measured on a spectrophotometer (UV Mini 1240) using Chronolab kits (Chronolab Systems, Barcelona, Spain). Low-density lipoprotein (LDL)-cholesterol was calculated using the Friedwald's formula [14].

\section{DNA extraction and molecular genotyping}

DNA was extracted from whole blood on filter paper by the Chelex method. Sixty-five participants (35 obese patients and 30 controls) were genotyped for TCF7L2 rs12255372 by polymerase chain reaction-restriction fragment length polymorphism (PCR-RFLP). The TCF7L2 rs12255372 (G/T) polymorphism was genotyped using the following primers: forward $5^{\prime}$-CTG GAA ACT AAG GCG TGA GG-3', reverse $5^{\prime}$-GGG TCG ATG TTG TTG AGC TT-3' (SIGMA-ALDRICH, St. Louis, Missouri, USA). A final reaction volume of $15 \mu \mathrm{L}$ for the PCR was constituted which contained $100 \mathrm{ng}$ of genomic DNA, 5 pmol of each primer, PCR buffer with $1 \mathrm{mmol} / \mathrm{L}$ of $\mathrm{MgCl}_{2}, 100 \mu \mathrm{mol} / \mathrm{L}$ of each deoxynucleotide triphosphate (dNTP), $0.5 \mathrm{U}$ of Hot Star Taq DNA polymerase (QIAGEN) and $7.8 \mu \mathrm{l}$ of nuclease-free water. The PCR was carried out in a BIOMETRA T3 Thermal Cycler under the following conditions: $95{ }^{\circ} \mathrm{C}$ for $15 \mathrm{~min}$, followed by 34 cycles of $95{ }^{\circ} \mathrm{C}$ for $30 \mathrm{~s}, 54{ }^{\circ} \mathrm{C}$ for $30 \mathrm{~s}, 72{ }^{\circ} \mathrm{C}$ for $30 \mathrm{~s}$, and a final extension of $72^{\circ} \mathrm{C}$ for $9 \mathrm{~min}$. The PCR amplicons (346 bp) were then digested with Thermus species (Tsp 5091) restriction enzyme at $37{ }^{\circ} \mathrm{C}$ overnight. The reaction volume was set to $15 \mu \mathrm{l}$, containing $7 \mu \mathrm{l}$ of amplicons, $1 \times$ NEB buffer1. The resulting products were separated by electrophoresis on a $3 \%$ agarose gel using a 100 bp DNA ladder and visualized under a UV transilluminator.

\section{Statistical analyses}

Allele and genotype frequencies in patients and control subjects were estimated by direct counting. Qualitative variables were analyzed by the Chi Square $\left(x^{2}\right)$ test with Yates' Continuity correction or the Exact test when appropriate using Epi Info version 6 (USD, Stone Mountain, USA). Quantitative variables were analysed 
by Mann-Whitney U test statistics using IBM SPSS for Windows version 20.0 (SPSS, Inc., Chicago, IL, USA). $\mathrm{P}<0.05$ was considered statistically significant and in case of multiple comparisons, the conservative Bonferroni correction was applied. The relative risks (RR) were calculated as odd ratios (OR) with $95 \%$ confidence interval (CI) using Woolf's formula.

\section{Ethical considerations}

The study was granted approval by the National Ethical Review Board of the Cameroon Ministry of Public Health. Written informed consent was obtained from all the participants. The study was conducted in accordance with the Helsinki Declaration.

\section{Results}

\section{Characteristics of the study population}

Table 1 shows anthropometric features, blood pressure and metabolic profile of the study population. Significant differences between obese patients and health controls were observed for age (median age-46.00 vs 25.00 years, $\mathrm{p}<0.0001$ ), waist-to-hip ratio (median value-0.8600 vs $0.8100, \mathrm{p}<0.0001$ ), diastolic blood pressure (median value -80.00 vs $68.00 \mathrm{mmHg}, \mathrm{p}<0.0040)$ and BMI (median value-32.76 vs $22.39 \mathrm{~kg} / \mathrm{m}^{2}, \mathrm{p}<0.0001$ ). All participants were positively genotyped. The respective fragments for the different genotypes were as follows. The wild type homozygote GG genotype had two band appearing at 143 and $104 \mathrm{bp}$; the mutant homozygote TT had two bands appearing at 126 and $104 \mathrm{bp}$ and the mutant heterozygote GT had three bands appearing at 143, 126 and $104 \mathrm{bp}$. Fragments smaller than $100 \mathrm{bp}$ migrated out of the gel and were not visualized (Figs. 1, 2).

\section{Genetic association assessment}

The TCF7L2 rs12255372 (G/T) SNP was in Hardy-Weinberg equilibrium in the general population $\left(\chi^{2}=0.0500\right.$, $\mathrm{p}=0.8300)$. The association between TCF7L2 and obesity in Cameroon was determined by comparing the allele and genotype frequencies of $\operatorname{rs} 12255372(G / T)$ in the 35 obese patients and 30 healthy controls (Table 2). The allelic frequencies obtained in the general population were $18.35 \%$ for the $\mathrm{T}$ allele and $81.65 \%$ for the $\mathrm{G}$ allele. In the case-control analysis, no significant difference was observed in the allelic and genotypic frequencies between the obese and non-obese groups $\left(\chi^{2}=0.0684, p=0.7900\right.$ for allele and $\chi^{2}=0.3720, p=0.5400$ for genotype).

\section{Genotype-phenotype correlation}

Genotype-phenotype correlations were performed to investigate the association of TCF7L2 rs12255372 and metabolic parameters in lean and obese individuals.
Table 1 Characteristics of the study population

\begin{tabular}{|c|c|c|c|}
\hline Characteristics & Non-obese $(n=30)$ & Obese $(n=35)$ & $P$ value \\
\hline \multicolumn{4}{|l|}{ Demographic } \\
\hline Sex, \% of male & $33.3 \%$ & $8.6 \%$ & 0.028 \\
\hline Age (years) & $25.00(23.00-36.50)$ & $46.00(39.00-53.00)$ & $<0.0001$ \\
\hline \multicolumn{4}{|l|}{ Clinical } \\
\hline WHR ratio & $0.81(0.77-0.84)$ & $0.86(0.83-0.93)$ & $<0.0001$ \\
\hline $\mathrm{SBP}(\mathrm{mmHg})$ & $\begin{array}{l}116.00(106.00- \\
125.00)\end{array}$ & $\begin{array}{l}125.00(117.00- \\
141.00)\end{array}$ & 0.27 \\
\hline $\mathrm{DBP}(\mathrm{mmHg})$ & $68.00(61.75-85.00)$ & $80.00(75.00-88.00)$ & 0.004 \\
\hline BMI $\left(\mathrm{kg} / \mathrm{m}^{2}\right)$ & $22.39(21.11-23.93)$ & $32.76(30.94-35.72)$ & $<0.0001$ \\
\hline \multicolumn{4}{|l|}{ Biological } \\
\hline FPG (g/L) & $90.00(83.00-103.25)$ & $96.00(86.00-103.00)$ & 0.392 \\
\hline $\mathrm{TC}(\mathrm{mg} / \mathrm{dL})$ & $\begin{array}{l}171.45(161.46- \\
192.83)\end{array}$ & $\begin{array}{l}181.94(172.26- \\
208.31)\end{array}$ & 0.093 \\
\hline $\begin{array}{l}\mathrm{HDL}-\mathrm{C}(\mathrm{mg} / \\
\quad \mathrm{dL})\end{array}$ & $46.79(42.71-50.16)$ & $47.96(43.70-51.72)$ & 0.247 \\
\hline $\mathrm{LDL}-\mathrm{C}(\mathrm{mg} / \mathrm{dL})$ & $100.05(92.87-120.24)$ & 106.97 (94.08-135.88) & 0.490 \\
\hline $\mathrm{TG}(\mathrm{mg} / \mathrm{dL})$ & $\begin{array}{l}125.29(120.50- \\
135.16)\end{array}$ & $\begin{array}{l}131.80(120.69- \\
144.83)\end{array}$ & 0.193 \\
\hline
\end{tabular}

Data are medians (interquartile range) unless otherwise stated

WHR waist-to-hip ratio, $S B P$ systolic blood pressure, $D B P$ diastolic blood pressure, $B M I$ body mass index, FPG fasting plasma glucose, $T C$ total cholesterol, $H D L$ high density lipoprotein cholesterol, LDL low density lipoprotein cholesterol, TG triglycerides

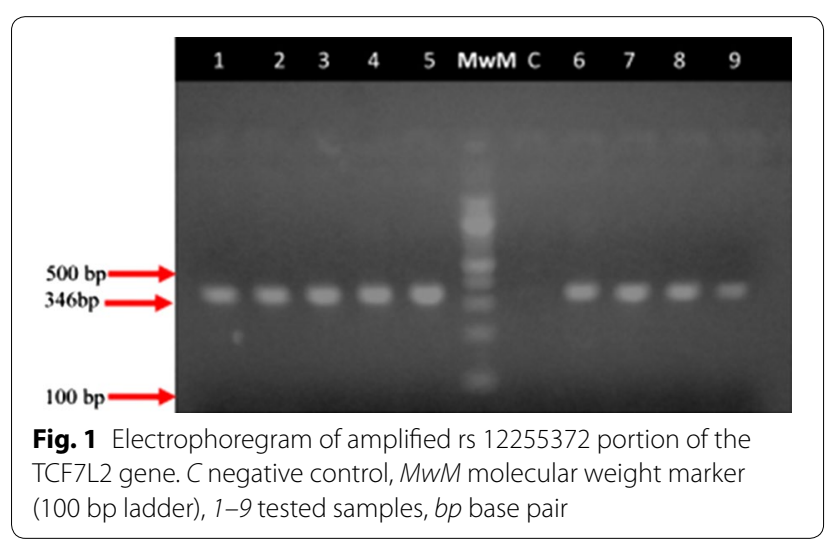

These case-control analyses were performed according to demographic (sex and age at onset), clinical (body mass index, waist-to-hip ratio, systolic and diastolic blood pressure) and biological (fasting plasma glucose, total cholesterol, HDL, LDL and triacylglycerol) characteristics. T allele carriers in the obese group had a significantly higher triglyceride levels when compared to their non-obese counterparts $(\mathrm{p}<0.0120)$.

\section{Discussion}

TCF7L2 has been associated with fasting plasma insulin, with glucose levels in type 2 diabetes patients to some 

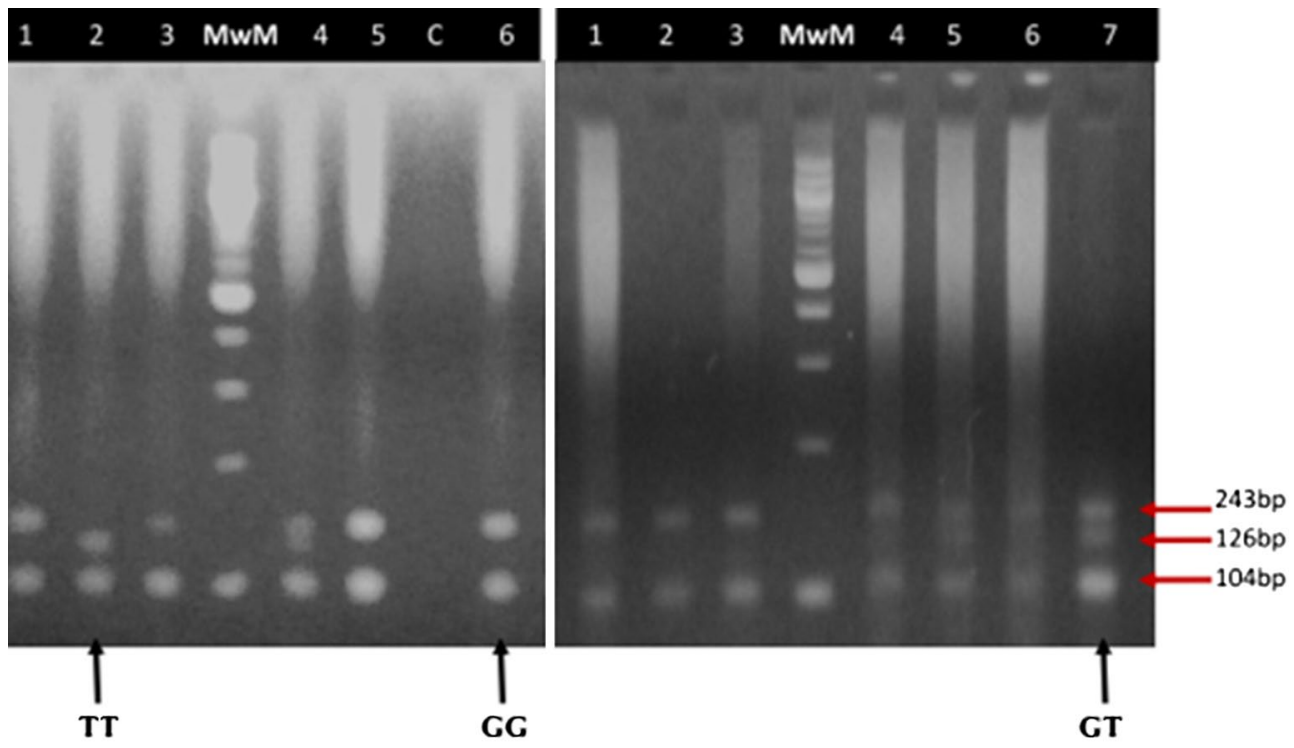

Fig. 2 Electrophoregram of digested amplicons with Tsp 5091. C negative control, MwM molecular weight marker (100 bp ladder), 1-6 and 1-7 tested samples, bp base pair

Table 2 Case-control association analysis of TCF7L2 rs12255372 (G/T) with obesity

\begin{tabular}{|c|c|c|c|c|c|}
\hline TCF7L2 rs12255372 G/T & Non-obese ${ }^{a}$ & Obese $^{a}$ & Test statistics & $P$ value & OR $(95 \% \mathrm{Cl})$ \\
\hline \multicolumn{6}{|l|}{ Alleles } \\
\hline G & $50(83.3)$ & $56(80)$ & $x^{2}=0.0684$ & 0.79 & $0.51(1.25-3.06)$ \\
\hline $\mathrm{T}$ & $10(16.7)$ & $14(20)$ & $x^{2}=0.0684$ & 0.79 & $0.33(0.80-1.96)$ \\
\hline Total (2n) & 60 & 70 & & & \\
\hline \multicolumn{6}{|l|}{ Genotypes } \\
\hline $\mathrm{G} / \mathrm{G}$ & $21(70)$ & $22(62.9)$ & $x^{2}=0.118$ & 0.73 & $1.38(0.49-3.90)$ \\
\hline $\mathrm{G} / \mathrm{T}$ & $8(26.7)$ & $12(34.3)$ & $x^{2}=0.155$ & 0.69 & $0.70(0.23-2.03)$ \\
\hline $\mathrm{T} / \mathrm{T}$ & $1(3.3)$ & $1(2.9)$ & $x^{2}=0.372$ & 0.54 & $1.17(0.07-19.59)$ \\
\hline Total (n) & 30 & 35 & & & \\
\hline
\end{tabular}

RR (relative risks) were calculated as odd ratios (OR) with $95 \%$ Cl using Woolf's formula. When one of the entries was zero, OR was calculated using Woolf's formula with Haldane's modification

a Data are given as $\mathrm{n}(\%)$ unless otherwise stated

extent with BMI $[10,15,16]$, and with adipogenesis [9]. It is one of the genes that have been identified as possible determinants of diabetes. Data on genetic susceptibility of African populations to chronic disease are very scarce [17]. The aim of this study was to assess the possible association of the TCF7L2 rs 12255372 polymorphism with obesity and weight-related traits in a Cameroonian population. This case-control association analysis demonstrates the absence of association between the polymorphism and obesity. This finding is similar to those of Cauchi et al. [10] and Saxena et al. [18] who also found no genetic association between TCF7L2 and obesity in European and US populations, respectively, especially for the rs7903146 and rs10885406 polymorphisms. However, some other studies reported a tendency for negative association with BMI $[10,19]$. Nevertheless, these results are different from those of Klunder et al. that showed a protective association between rs 12255372 polymorphism and obesity in Mexican children, while a deleterious effect of this variant was observed in diabetic adults [11]. Moreover, the background frequencies of the TCF7L2 rs12255372 alleles and genotypes were different between the Cameroonian and Mexican populations indicating genetic heterogeneity across populations and ancestries on this locus. The frequency of this risk allele has been observed to be highest in a study in Caucasians 
(77\%) with $42 \%$ in cases (diabetics) and $35 \%$ in controls [20] and lowest in Asians (1\%) with $0.6 \%$ in cases and $0.4 \%$ in controls [21].

Studies have shown that some variants of TCF7L2 are associated with impaired lipid metabolism, especially a trend towards higher triglycerides, with an adverse effect on cardiovascular risk and stroke incidence [22, 23]. Meta-analyses have been conducted to confirm the association from individual studies. These studies (meta-analyses) further support the association between TCF7L2 gene and metabolic diseases including diabetes and obesity. Among the common studied allele, rs12255372 variant of the TCF7L2 gene is significantly associated with susceptibility to T2DM in the global population [24] while the other allele (rs7903146) is associated with metabolic syndrome [25] of which dyslipidemia is a predictor. TCF7L2 rs12255372 has also been found to be associated with high serum triglycerides and was differentially expressed in adipose tissue in families with familial combined hyperlipidaemia [26]. Genotype-phenotype correlation assessment in our study revealed that the gene was preferentially associated with high triglyceride levels. Carriers of the $\mathrm{T}$ risk allele had a significantly higher triglyceride level when compared to carriers of the $\mathrm{G}$ allele $(\mathrm{p}<0.0120)$. This finding suggests a possible association between the TCF7L2 rs12255372 variant and cardiovascular risk in the Cameroonian population. Further studies are therefore required to confirm these findings and then investigate the nature of the association.

\section{Conclusion}

TCF7L2 rs12255372 was not associated with obesity in this Cameroonian population, but was associated with higher triglyceride levels in obese patients. Due to the small sample size of the study and the lack of power to detect an association, other studies carried with a larger sample size and matched for age and sex are required to confirm these findings.

\section{Authors' contributions}

Study conception and design: ES, BAT, RDD, MSE, WFM, JCM. Data collection: ENN, MGF, ES, BAT, OSD, EPMM, PPF, ED, RDD, MSE. Statistical analysis: OSD, JJNN, FA. Drafting: ENN, JJNN, MGF, OSD, EPMM, PPF, RDD, MSE, FA. Critical discussion and manuscript revision: ES, BAT, JJNN, WFM, JCM. All authors read and approved the final manuscript.

\footnotetext{
Author details

1 Department of Biochemistry, Faculty of Science, University of Yaoundé I, Yaoundé, Cameroon. ${ }^{2}$ Laboratory for Molecular Medicine and Metabolism, Biotechnology Center, University of Yaoundé I, Yaoundé, Cameroon. ${ }^{3}$ Department of Internal Medicine and Specialties, Faculty of Medicine and Biomedical Sciences, University of Yaoundé I, Yaoundé, Cameroon. ${ }^{4}$ National Obesity Center, Yaoundé Central Hospital, Yaoundé, Cameroon. ${ }^{5}$ Department of Medicine, Groote Schuur Hospital and University of Cape Town, Cape Town, South Africa. ${ }^{6}$ Medical Diagnostic Center, Yaoundé, Cameroon. ${ }^{7}$ The Canadian Pharmacogenomics Network for Drug Safety (CPNDS), Center for Molecular Medicine and Therapeutics, Department of Medical Genetics, University of British Columbia, Vancouver, Canada. ${ }^{8}$ Laboratory for Public
}

Health Research Biotechnologies, Biotechnology Center, University of Yaoundé I, Yaoundé, Cameroon.

\section{Acknowledgements}

We gratefully acknowledge all the patients who accepted to take part in this study. We are also grateful to the staff of the National Obesity Centre and the Biotechnology Center of the University of Yaounde I for their contribution in the recruitment of patients and the handling of samples, assays and records. This work was supported by a grant from the Vlaamse Inter Universitaire Raad (VLIR-UOS ZEIN2007PR343). The study was also supported by the North East Diabetes Trust, Newcastle upon Tyne, and the Institute of Health and Society, Newcastle University, UK.

\section{Competing interests}

The authors declare that they have no competing interests.

Received: 28 December 2014 Accepted: 2 November 2015

Published online: 25 November 2015

\section{References}

1. Ng M, Fleming T, Robinson M, Thomson B, Graetz N, Margono C, et al. Global, regional, and national prevalence of overweight and obesity in children and adults during 1980-2013: a systematic analysis for the Global Burden of Disease Study 2013. Lancet. 2014;384(9945):766-81.

2. Lim SS, Vos T, Flaxman AD, Danaei G, Shibuya K, Adair-Rohani H, et al. A comparative risk assessment of burden of disease and injury attributable to 67 risk factors and risk factor clusters in 21 regions, 1990-2010: a systematic analysis for the Global Burden of Disease Study 2010. Lancet. 2012;380(9859):2224-60.

3. Sobngwi E, Mbanya JC, Unwin NC, Kengne AP, Fezeu L, Minkoulou EM, Aspray TJ, Alberti KG. Physical activity and its relationship with obesity, hypertensionand diabetes in urban and rural Cameroon. Int J Obes Relat Metab Disord. 2002;26(7):1009-16.

4. Kamadjeu RM, Edwards R, Atanga JS, Kiawi EC, Unwin N, Mbanya JC. Anthropometry measures and prevalence of obesity in the urban adult population of Cameroon: an update from the Cameroon Burden of Diabetes Baseline Survey. BMC Public Health. 2006;6:228.

5. Speakman JR. Obesity: the integrated roles of environment and genetics. J Nutr. 2004;134:2090S-105S.

6. Lyon HN, Hirschorn JN. Genetics of common forms of obesity: a brief overview. Am J Clin Nutr. 2005;82(1 Suppl):215S-7S.

7. Yang W, Kelly T, He J. Genetic epidemiology of obesity. Epidemiol Rev. 2007;29:49-61.

8. Moon RT, Brown JD, Torres M. WNTs modulate cell fate and behavior during vertebrate development. Trends Genet. 1997;13:157-62.

9. Ross SE, Hemati N, Longo KA, Bennett CN, Lucas PC, Erikson RL, MacDougald OA. Inhibition of adipogenesis by Wnt signaling. Science. 2000;289(5481):950-3.

10. Caushi S, Choquet H, Gutierrez-Aguilar R, Capel F, Grau K, Proenca C, et al. Effects of TCF7L2 polymorphisms on obesity in European populations. Obesity (Silver Spring). 2008;16(2):476-82.

11. Klunder-Kluender M, Mejia-Benitez MA, Flores-Huerta S, Burguete-Garcia Al, Garcia-Mena J, Cruz M. rs12255372 variant of TCF7L2 gene is protective for obesity in Mexican children. Arch Med Res. 2011;42(6):495-501.

12. Nanfa D, Sobngwi E, Atogho-Tiedeu B, Noubiap JJ, Donfack OS, Mofo EP, Guewo-Fokeng M, Nguimmo Metsadjio A, Ndonwi Ngwa E, Pokam Fosso P, Djahmeni E, Djokam-Dadjeu R, Evehe MS, Aminkeng F, Mbacham WF, Mbanya JC. Association between the TCF7L2 rs12255372 (G/T) gene polymorphism and type 2 diabetes mellitus in a Cameroonian population: a pilot study. Clin Transl Med. 2015;4:17.

13. Guewo-Fokeng M, Sobngwi E, Atogho-Tiedeu B, Donfack OS, Noubiap JJ, Ngwa EN, Mato-Mofo EP, Fosso PP, Djahmeni E, Djokam-Dadjeu R, Evehe MS, Aminkeng F, Mbacham WF, Mbanya JC. Contribution of the TCF7L2 rs7903146 (C/T) gene polymorphism to the susceptibility to type 2 diabetes mellitus in Cameroon. J Diabetes Metab Disord. 2015;14(14):26.

14. Friedewald WT, Levy RI, Fredrickson DS. Estimation of low density lipoprotein cholesterol without the use of the preparative ultracentrifuge. Clin Chem. 1972;18(6):499-502. 
15. Grant SFA, Thorleifsson G, Reynisdottir I, et al. Variant of transcription factor 7-like 2 (TCF7L2) gene confers risk of type 2 diabetes. Nat Genet. 2006:38:320-3.

16. Gjesing A, Kjems L, Vestmar M, et al. Carriers of the TCF7L2 rs7903146 TT genotype have elevated levels of plasma glucose, serum proinsulin and plasma gastric inhibitory polypeptide (GIP) during a meal test. Diabetologia. 2011;54:103-10

17. H3Africa Consortium. Research capacity. Enabling the genomic revolution in Africa. Science. 2014;344(6190):1346-8.

18. Saxena R, Gianniny L, Burtt NP, et al. Common single nucleotide polymorphisms in TCF7L2 are reproducibly associated with type 2 diabetes and reduce the insulin response to glucose in nondiabetic individuals. Diabetes. 2006;55:2890-5.

19. Florez JC, Jablonski KA, Bayley N, et al. TCF7L2 polymorphisms and progression to diabetes in the Diabetes Prevention Program. N Engl J Med. 2006;355:241-50.

20. Wang J, Zhang J, Li L, Wang Y, Wang Q, Zhai Y, You H, Hu D. Association of rs 12255372 in the TCF7L2 gene with type 2 diabetes mellitus: a metaanalysis. Braz J Med Biol Res. 2013;46:382-93.

21. Rangel SR, Queiroz-Araújo EM, Oliveira de Matos EM, Carvalho G, Souza-Rios DL. The rs7903146 SNP of TCF7L2 gene and its association with the metabolic syndrome: a review. Braz J Med Human Health. 2014;2(3):111-22.

22. Perez-Martinez P, Perez-Caballero Al, Garcia-Rios A, Yubero-Serrano EM, Camargo A, Gomez-Luna MJ, Marin C, Gomez-Luna P, Dembinska-Kiec A, Rodriguez-Cantalejo F, Tinahones FJ, Roche HM, Perez-Jimenez F,
Lopez-Miranda J, Delgado-Lista J. Effects of rs7903146 variation in the TCF7L2 gene in the lipid metabolism of three different populations. PLoS One. 2012;7(8):e43390.

23. Corella D, Carrasco P, Sorli JV, Estruch R, Rico-Sanz J, Martinez-Gonzalez MA, Salas-Salvado J, Covas MI, Coltell O, Aros F, Lapetra J, Serra-Majem L, Ruiz-Gutierrez V, Wanberg J, Fiol M, Pinto X, Ortega-Azorin C, Munoz MA Martinez JA, Gomez-Gracia E, Gonzalez JI, Ros E, Ordovas JM. Mediterranean diet reduces the adverse effect of the TCF7L2-rs7903146 polymorphism on cardiovascular risk factors and stroke incidence: a randomized controlled trial in a high-cardiovascular-risk population. Diabetes Care. 2013;36(11):3803-11.

24. Damcott CM, Pollin TI, Reinhart LJ, Ott SH, Shen H, Silver KD, et al. Polymorphisms in the transcription factor 7-like 2 (TCF7L2) gene are associated with type 2 diabetes in the Amish: replication and evidence for a role in both insulin secretion and insulin resistance. Diabetes. 2006:55:2654-9.

25. Chang YC, Chang TJ, Jiang YD, Kuo SS, Lee KC, Chiu KC, et al. Association study of the genetic polymorphisms of the transcription factor 7-like 2 (TCF7L2) gene and type 2 diabetes in the Chinese population. Diabetes. 2007;56:2631-7.

26. Huertas-Vazquez A, Plaisier C, Weissglas-Volkov D, Sinsheimer J, CanizalesQuinteros S, Cruz-Bautista I, Nikkola E, Herrera-Hernandez M, Davila-Cervantes A, Tusie-Luna T, Taskinen MR, Aquilar-Salinas C, Pajukanta P. TCF7L2 is associated with high serum triacylglycerol and differentially expressed in adipose tissue in families with familial combined hyperlipidaemia. Diabetologia. 2008;51(1):62-9.

\section{Submit your next manuscript to BioMed Central and take full advantage of:}

- Convenient online submission

- Thorough peer review

- No space constraints or color figure charges

- Immediate publication on acceptance

- Inclusion in PubMed, CAS, Scopus and Google Scholar

- Research which is freely available for redistribution

Submit your manuscript at 